Article

\title{
Biomedical Application of a Herbal Product Based on Two Asteraceae Species
}

\author{
Alice Grigore ${ }^{1, *}$, Georgeta Neagu ${ }^{1}$, Sultana Nita ${ }^{1}$, Carmen Ionita ${ }^{2, *}$, Lucian Ionita ${ }^{2}$, \\ Ana-Maria Goanta ${ }^{2}$, Cristina Fernoaga ${ }^{2}$, Valerica Danacu ${ }^{2}$ and Radu Albulescu ${ }^{1}$ \\ 1 National Institute for Chemical-Pharmaceutical Research and Development-ICCF Bucharest, Calea Vitan, \\ no. 112, 3rd District, 031299 Bucharest, Romania; georgetaneagu2008@gmail.com (G.N.); \\ nitasultanaiccf@gmail.com (S.N.); radu.albulescu1@gmail.com (R.A.) \\ 2 Faculty of Veterinary Medicine, University of Agronomic Sciences and Veterinary Medicine of Bucharest, \\ 59 Marasti Blvd., 1st District, 011464 Bucharest, Romania; ionital@yahoo.com (L.I.); \\ ana_mv@yahoo.com (A.-M.G.); cfernoaga@yahoo.com (C.F.); valericadanacu160@gmail.com (V.D.) \\ * Correspondence: alicella587@gmail.com (A.G.); ionitacarmen757@gmail.com (C.I.)
}

Received: 21 August 2020; Accepted: 14 September 2020; Published: 16 September 2020

Featured Application: Immunomodulatory herbal product with application in veterinary area for companion animals with periodontal diseases.

\begin{abstract}
Background: Species belonging to the Asteraceae family have been widely studied for their healing properties. The paper introduces STOMAPET (patent pending A2016/00888/23.11.2016) based on Eupatorium cannabinum (hemp-agrimony) and Inula helenium (elecampagne) and its potential application in diseases of the oral system. Methods: STOMAPET was prepared according to the patent application and HPLC analysis was performed for chemical analysis. In vitro studies were performed using human monocytes and the cells' viability was determined by MTS assay. In vivo studies involved lipopolysaccharide (LPS)-induced murine endotoxemia and veterinary clinical case reports. Results: HPLC analysis revealed various phenolic compounds and alantolactone. In in vitro studies, monocytes viability remained stable, around and above $100 \%$ at all concentrations ( 7.8 to $250 \mu \mathrm{g} / \mathrm{mL}$ ), and a high stimulatory effect on cell proliferation was noted. In LPS-induced murine endotoxemia, STOMAPET prevents mortality, improves the decrease in body mass, and prevents the drop in temperature. Case reports of companion animals with oral diseases ameliorated after STOMAPET treatment are presented. Conclusions: Preclinical studies confirmed the safety of STOMAPET and its pharmacological potential. The results of the veterinary case reports are also encouraging. More studies are needed to find the precise mechanism of action in correlation to chemical composition.
\end{abstract}

Keywords: Inula helenium; Eupatorium cannabinum; periodontal disease; immunomodulation; endotoxemia

\section{Introduction}

Species belonging to the Asteraceae family have been widely studied for their antimicrobial, anti-inflammatory, anticancer, and insecticidal properties [1]. Inflammation, probably the most vital immune response induced by noxious stimuli or conditions, is an essential component of innate immunity as first line of defense against pathogens such as bacteria, viruses, or fungi [2].

The literature contains numerous studies of the genus Eupatorium with use of plant extracts and essential oils for the development of new drugs for veterinary and human use [3]. Extracts of several species are potent antiinflammatory or immunomodulatory agents: aqueous extract of Eupatorium fortunei [4], ethanolic extract of E. japonicum [5], flavonoids fraction of E. lindleyanum [6], ethanolic leaf extract of E. adenophorum [7], methanolic, ethanolic, dichloromethane extracts of E. perfoliatum [8], etc. Flavonoids 
and terpenes have been identified as the two main chemical constituents of Eupatorium [9]. It was shown both in in vitro $[8,10]$ and in vivo assays [6] that the antiinflammatory activity of Eupatorium main compounds is exerted on the gene and protein level by down-regulation of proinflammatory mediators (CSF-3, IL-1 $\alpha$, IL-1 $\beta$, IL-6, and TNF- $\alpha$ ), chemokines (CCL2, CCL22, and CXCL10), and inhibition of nitric oxide $(\mathrm{NO})$ release.

Moreover, another genus belonging to the Asteraceae family, Inula, is traditionally used in Europe as a valuable source of active compounds with anti-inflammatory activity-I. cappa [11], I. helenium [12], I. japonica [13], etc. Sesquiterpene lactones, mainly alantolactone and isoalantolactone, are considered as its active ingredients [14]. In experimental models of inflammation, these compounds supress nitric oxide production and other proinflammatory cytokines via the downregulation of nuclear factor kappa B (NF-kB) and TNF receptor associated factor 6 (TRAF6) [15-19], interfere with leukotriene synthesis and phospholipase A2-induced mastocyte release of inflammatory mediators [20], stabilize lysosomal membranes, and induce an antiproliferative effect [21].

This paper introduces STOMAPET (patent pending A2016/00888/23.11.2016) based on Eupatorium cannabinum (hemp-agrimony) and Inula helenium (elecampagne) extracts and its potential as immunomodulatory agent, proved by preclinical studies. Several case reports from veterinary area demonstrated that STOMAPET could be applied successfully as healing, antiinflammatory, and antiseptic agent in diseases of the oral system.

\section{Materials and Methods}

\subsection{Method of Preparation (According to Patent Application No. A2016/00888/23.11.2016)}

The extract was prepared by soaking $50 \mathrm{~g}$ of Eupatoriae herba and $50 \mathrm{~g}$ of Inulae radix in $500 \mathrm{~mL}$ $70 \%$ ethanol $(1: 10 \mathrm{w} / \mathrm{v})$ for 10 days at room temperature, followed by filtration and concentration under reduced pressure (72-74 mmHg). The resulted spiss (17.04 g) was dissolved in $20 \%$ dimethyl sulfoxide (DMSO) to obtain a stock solution of $0.25 \mathrm{~g} / \mathrm{mL}$.

\subsection{HPLC Analysis}

STOMAPET solution was analyzed on a HPLC ELITE-LaChrom system, with DAD detector; an Inertsil ODS 3 column $(250 \times 4.6 \mathrm{~mm}, 5 \mu \mathrm{m})$ at $23{ }^{\circ} \mathrm{C}$, using a gradient elution. Separation of polyphenols was performed using a mobile phase consisting of an A solution (water acidified with phosphoric acid, $\mathrm{pH}=2.5$ ) and a $\mathrm{B}$ solution (methanol) at an initial flow rate of $1 \mathrm{~mL} / \mathrm{min}$, with an injection of $20 \mu \mathrm{L}$ [22]. Separation of sesquiterpene lactones was done on the above mentioned column in the isocratic mode, using $60 \%$ methanol at a flow rate of $1 \mathrm{~mL} / \mathrm{min}$, with an injection volume of $10 \mu \mathrm{L}$ [23].

Alantolactone, rutin, caffeic, and chlorogenic acids were from Sigma Aldrich (Darmstadt, Germany) and used as reference substances.

\subsection{In Vitro Studies}

\subsubsection{Cell Lines and Culture Conditions}

Human monocytes (SC line) were purchased from Americal Type Culture Collection (ATCC, Manassas, VA, USA) and maintained in culture according to manufacturer indications. Viability assays were carried out on 96-well microplates (Corning, New York, NY, USA). DMSO and bacterial lipopolysaccharide (E. coli LPS K-235) were purchased from Sigma Aldrich (Germany). The medium was replaced two to three times per week. Once a week, the non-adherent cell line was established by centrifugation and subsequent resuspension at $1 \times 10^{6}$ viable cells $/ \mathrm{mL}$. 
2.3.2. Evaluation of Viability and Survival of Non-Stimulated and lipopolysaccharide (LPS)-Stimulated Macrophages

The assay was used to assess the potential cytotoxic effect of STOMAPET on a normal human monocytes cell line and also to evaluate its influence in the case of LPS stimulation. Cells were seeded into 96-well plates $\left(1 \times 10^{4}\right.$ cells/well $)$ and after $24 \mathrm{~h}$ further treated with several dilutions of extracts ranging from 7.8 to $250 \mu \mathrm{g} / \mathrm{mL}$ in triplicate. Negative control consisted of a mixture of DMSO and water (extracts solvent) diluted with culture media. The cells were incubated with the treatments for 24/48 h, after which an MTS assay (CellTiter 96-Aqueous One Solution Cell Proliferation Assay ${ }^{\circledR}$, Promega) was carried out, according to manufacturer's instructions. The absorbance was measured at $492 \mathrm{~nm}$ with LKB Chameleon microplate reader. Cell viability was expressed as a percentage of live treated cells compared with live control cells.

In the LPS-stimulated macrophages assay, cells were treated with serum-free media supplemented with several dilutions of extracts $(7.8$ to $250 \mu \mathrm{g} / \mathrm{mL})$ in the presence of LPS $(10 \mu \mathrm{g} / \mathrm{mL})$ for $18 \mathrm{~h}$. LPS alone served as negative control. The cells' viability was evaluated by MTS assay as described above.

\subsection{In Vivo Studies}

\subsubsection{Preclinical Studies}

LPS-Induced Endotoxemia in Mice

Animals

Male NMRI mice (18-20 g, 6-8-weeks old) were purchased from Cantacuzino Institute (Bucharest, Romania). The mice were housed in a temperature-controlled room $\left(24^{\circ} \mathrm{C}\right)$ with a relative humidity of $40-80 \%$ and a 12-h light-dark cycle, with ad libitum access to standard food and filtered water. Mice were acclimatized for 3 days prior to initiation of any experimental protocols. All experiments were approved by the Ethical Committee of the Institute, in accordance to regulations issued by FELASA (Federation of European Laboratory Animal Science Associations) and ARSAL (Romanian Association for Laboratory Animal Science).

Induction of Shock and Treatment Regimen

To test the effect of STOMAPET against LPS-induced mortality, the drug was administered IP at $1 \mathrm{~mL} / 20 \mathrm{~g}$ at $24 \mathrm{~h}$ prior to the LPS challenge. For this study, three groups of mice ( $\mathrm{n}=5 /$ group) were created prior to any injections, i.e., control (vehicle), LPS $(20 \mathrm{mg} / \mathrm{kg})$ only, and STOMAPET $(0.25 \mathrm{~g} / \mathrm{mL})$ + LPS. Survival in each group was assessed every $12 \mathrm{~h}$ for a period of 7 days.

\subsubsection{Clinical Cases}

To test the efficiency of STOMAPET in periodontal diseases of companion animals, representative cases from the Clinic of the Faculty of Veterinary Medicine (Bucharest, Romania) were selected and treated after the owner's written consent.

Statistical Analysis

The results were expressed as means \pm S.D. of three independent experiments. $p<0.05$ was statistically significant. All analysis were performed with GraphPad Prism (version 8.4.3; GraphPad Software Inc.; San Diego, CA, USA).

\subsection{Ethical Statement}

All preclinical in vivo experiments were approved by the Ethical Committee of the Institute, in accordance to European regulations. For clinical cases, all owners gave their informed consent for inclusion of their pets before they participated in the study. The study was conducted in accordance 
with the Declaration of Helsinki, and the protocol was approved by the Ethics Committee of Faculty of Veterinary Medicine from Bucharest (ST19/1).

\section{Results}

\subsection{HPLC Analysis}

HPLC analysis revealed $30.171 \pm 0.02 \mathrm{mg} / 100 \mathrm{~mL}$ chlorogenic acid, $3.074 \pm 0.01 \mathrm{mg} / 100 \mathrm{~mL}$ caffeic acid, $0.514 \pm 0.02 \mathrm{mg} / 100 \mathrm{~mL}$ rosmarinic acid, $4.085 \pm 0.03 \mathrm{mg} / 100 \mathrm{~mL}$ gallic acid, $0.768 \pm 0.02 \mathrm{mg} / 100 \mathrm{~mL}$ 3,4 dihydroxybenzoic acid, $60.742 \pm 0.02 \mathrm{mg} / 100 \mathrm{~mL}$ 2,5 dihydroxybenzoic acid, $23.862 \pm 0.03 \mathrm{mg} / 100 \mathrm{~mL}$ rutin, $1.638 \pm 0.01 \mathrm{mg} / 100 \mathrm{~mL}$ quercetin, $0.557 \pm 0.03 \mathrm{mg} / 100 \mathrm{~mL}$ kaempferol, and $0.207 \pm 0.03 \mathrm{mg} / 100 \mathrm{~mL}$ alantolactone (Figures 1-3).

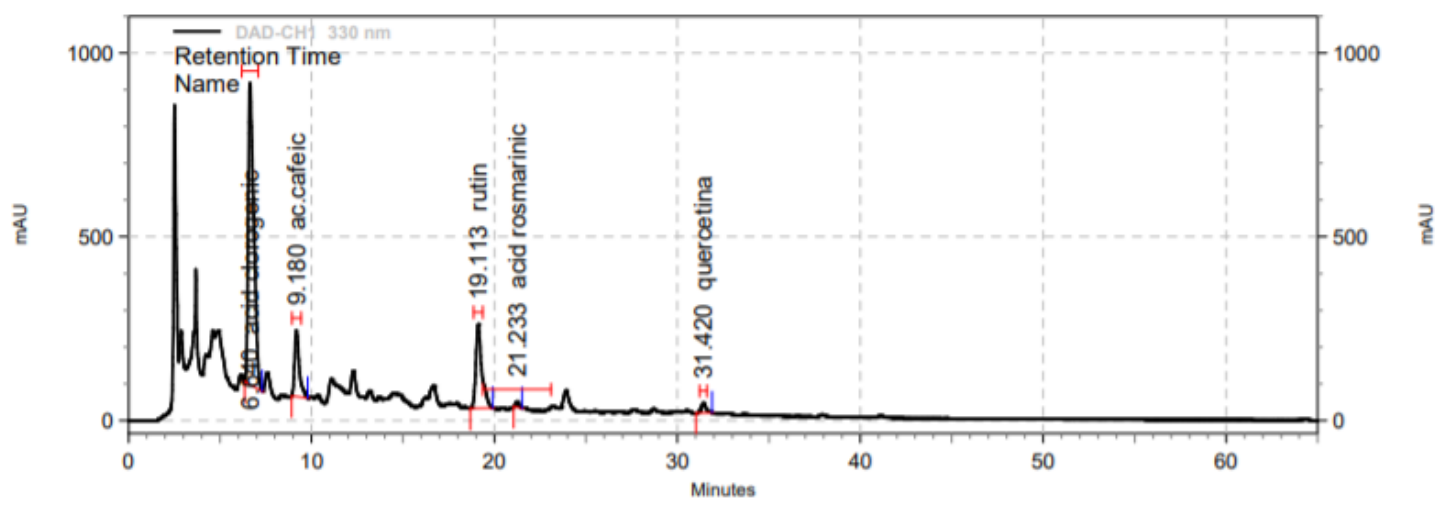

Figure 1. HPLC chromatograms of STOMAPET at $330 \mathrm{~nm}$-hydroxycinnamic acids and flavonoids.

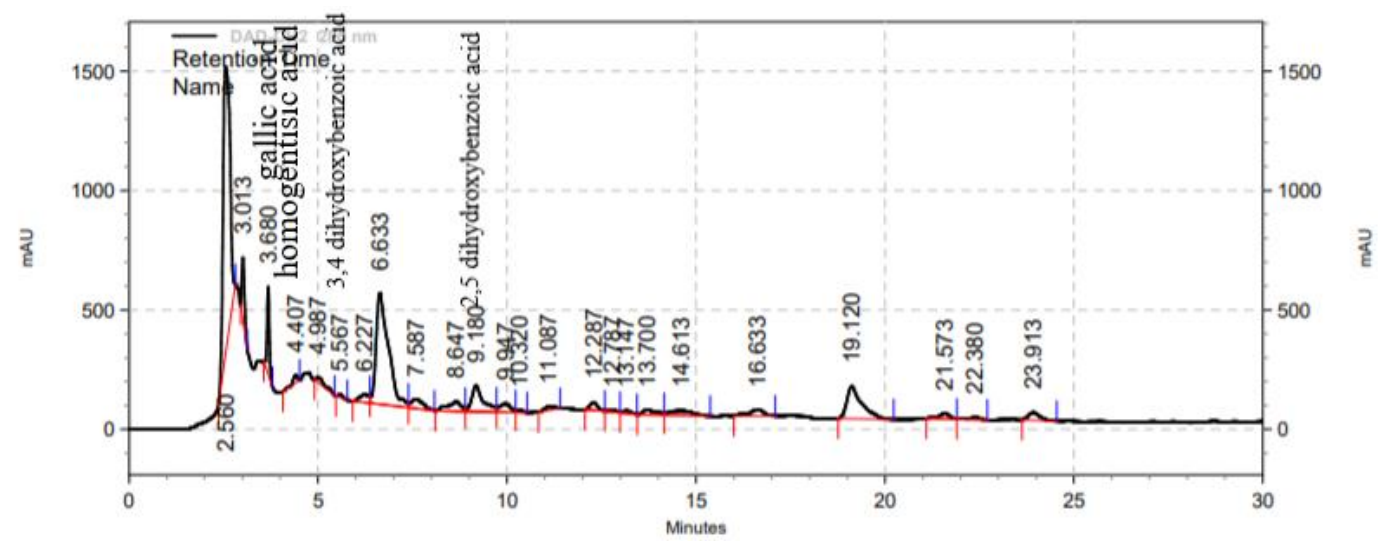

Figure 2. HPLC chromatograms of STOMAPET at $280 \mathrm{~nm}$-hydroxybenzoic derivatives.

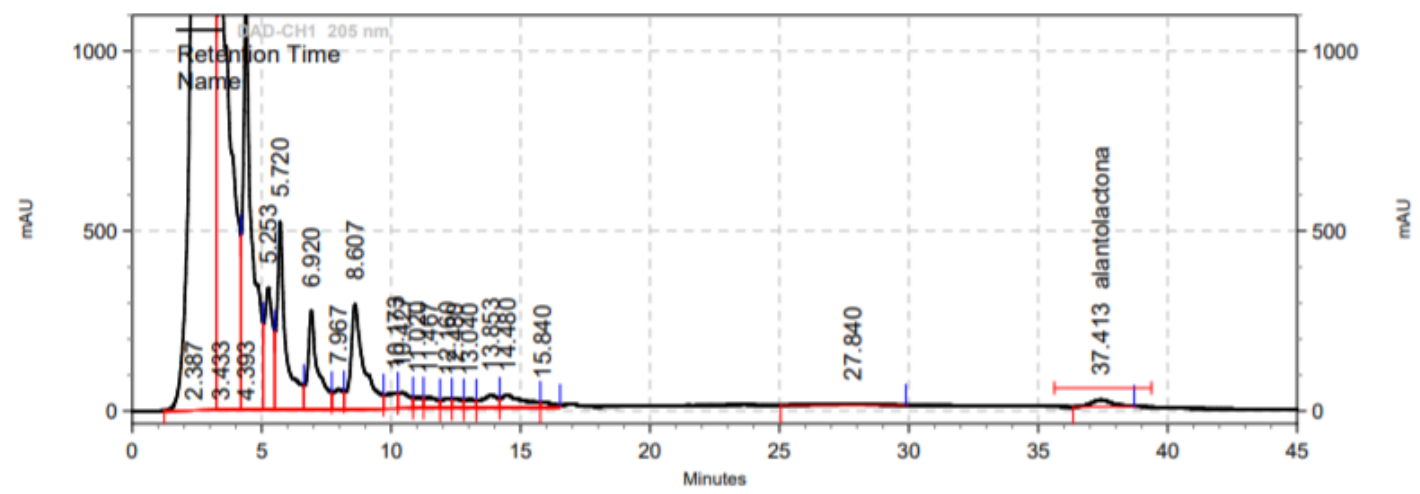

Figure 3. HPLC chromatograms of STOMAPET at $205 \mathrm{~nm}$-alantolactone. 


\subsection{In Vitro Studies}

Cell viability after treatment with various concentrations of STOMAPET was determined using a human monocyte culture and evaluated by MTS assay. The SC cell viability remained stable, around and above $100 \%$ at all concentrations of the extract (7.8 to $250 \mu \mathrm{g} / \mathrm{mL}$ ) (Figure 4 ).

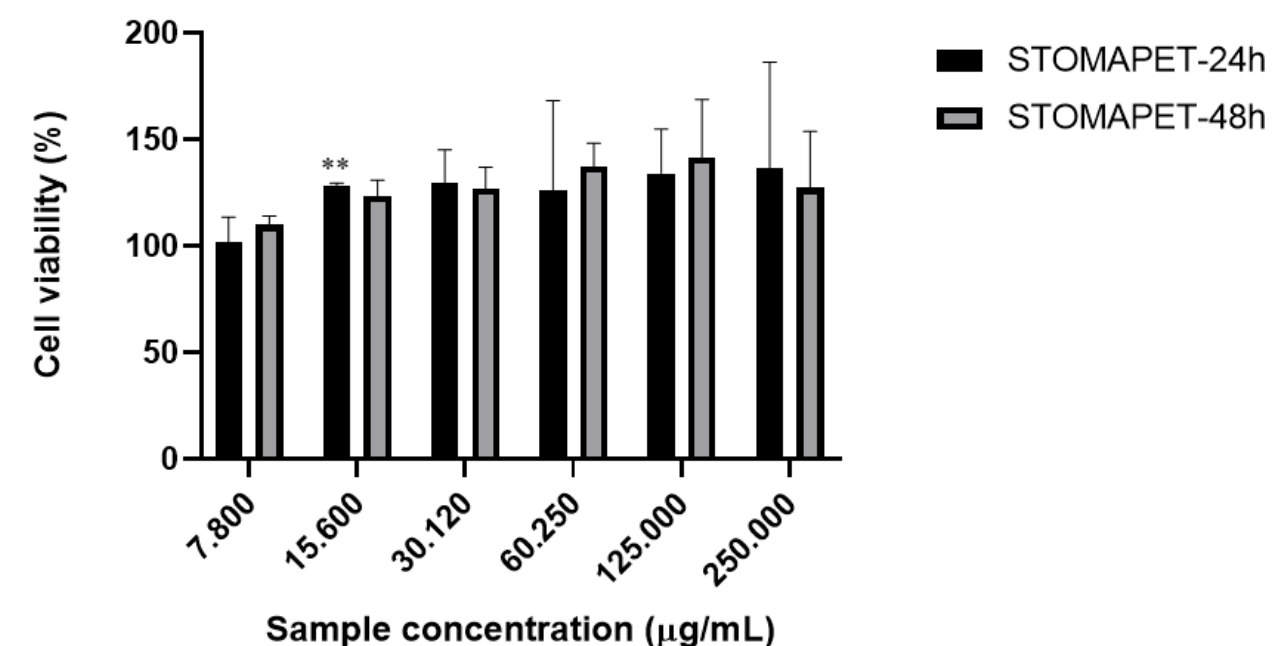

Figure 4. The effect of STOMAPET on SC cells exposed for 24 and $48 \mathrm{~h}$ (MTS assay). Values represent mean $\pm \operatorname{SD}\left(\mathrm{n}=3,{ }^{*} p<0.05,{ }^{* *} p<0.01,{ }^{* * *} p<0.001\right)$.

In LPS-stimulated macrophages, the product induced a protective effect only at high doses and only after $24 \mathrm{~h}$ of exposure. After $48 \mathrm{~h}$, cells viability dropped close to the LPS group level. (Figure 5).

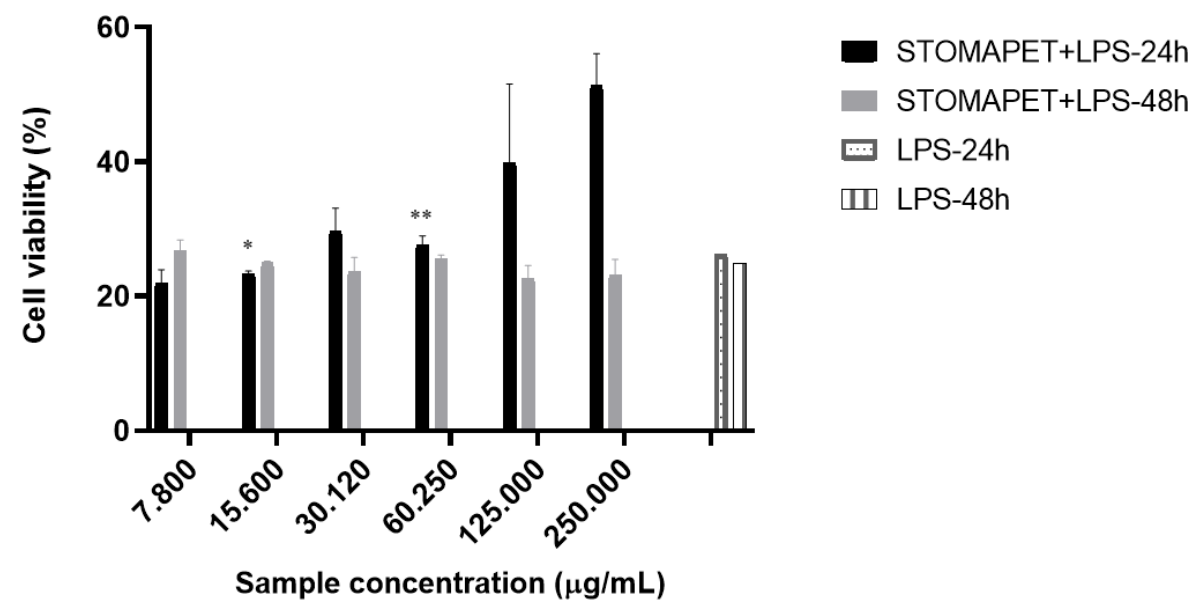

Figure 5. The effect of STOMAPET on LPS-stimulated SC cells exposed for 24 and $48 \mathrm{~h}$ (MTS assay).

Values represent mean $\pm \operatorname{SD}\left(\mathrm{n}=3,{ }^{*} p<0.05,{ }^{* *} p<0.01,{ }^{* * *} p<0.001\right)$.

\subsection{In Vivo Studies}

\subsubsection{Preclinical Studies}

LPS-induced endotoxemia in mice is a reference assay for inducing a high systemic inflammatory response [24]. Suppressing this response by various agents could counteract the endotoxic sepsis and organ dysfunction, increasing survival. In Group 1, following LPS injection, 1 mouse died after $24 \mathrm{~h}$, 3 mice after $45 \mathrm{~h}$, and 1 mouse after $47 \mathrm{~h}$. Group 2 mice injected with LPS and treated with STOMAPET survived. Figure 6 describes the survival rate of mice as a function of time since LPS injection (in hours) for Group 1 (black line) and Group 2 (red line). 


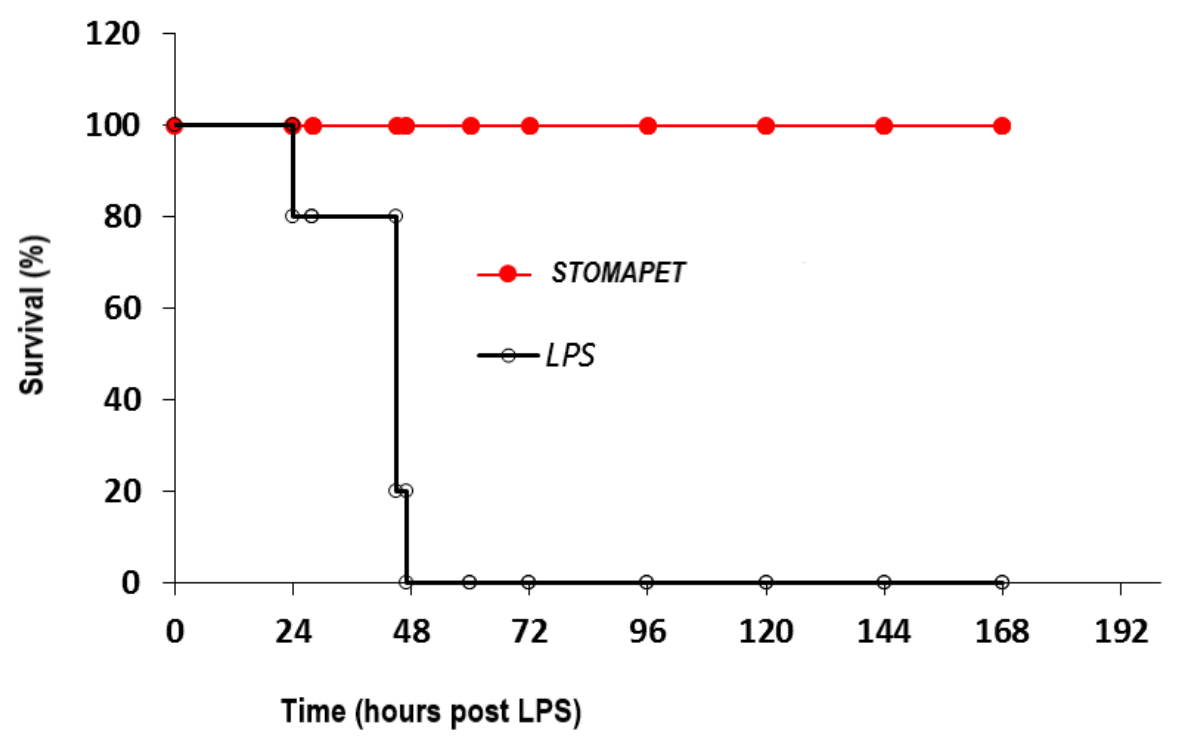

Figure 6. Mortality caused by LPS-induced endotoxemia is prevented by treatment with STOMAPET. Survival rate (\%) analyzed according to the time (hours) elapsed since the intraperitoneal injection with LPS (20 mg/kg mouse mass). Group 1 (black line): $\mathrm{n}=5$ mice, Group 2 (red line): $\mathrm{n}=5$ mice.

Mice in the two groups were weighed at the time of LPS injection and once every $24 \mathrm{~h}$ after injection for $168 \mathrm{~h}$. Figure 2 shows the body mass dependence (g) as mean \pm SEM of the masses of the 5 mice as a function of the time (hours) elapsed since the LPS injection. In Group 1 (black line) there was a significant decrease in body weight $(p=0.0130<0.05)$ at $24 \mathrm{~h}$ after LPS injection compared with mass at the time of LPS injection ( $0 \mathrm{~h}$ ). In Group 1, at $48 \mathrm{~h}$, no mice survived (see Figure 1). In Group 2 (red line), there was a significant decrease in body weight at $48 \mathrm{~h}(p=0.0113<0.05)$ and $72 \mathrm{~h}(p=0.0044$ $<0.05)$ from the time of LPS injection (0 h). However, at $24 \mathrm{~h}(p=0.0577), 144 \mathrm{~h}(p=0.2394)$, and $168 \mathrm{~h}$ $(p=0.0754)$, the decreases are insignificant compared to the time of LPS injection (hours) showing that STOMAPET improves in time the decrease in body mass caused by LPS-induced endotoxemia (Figure 7).

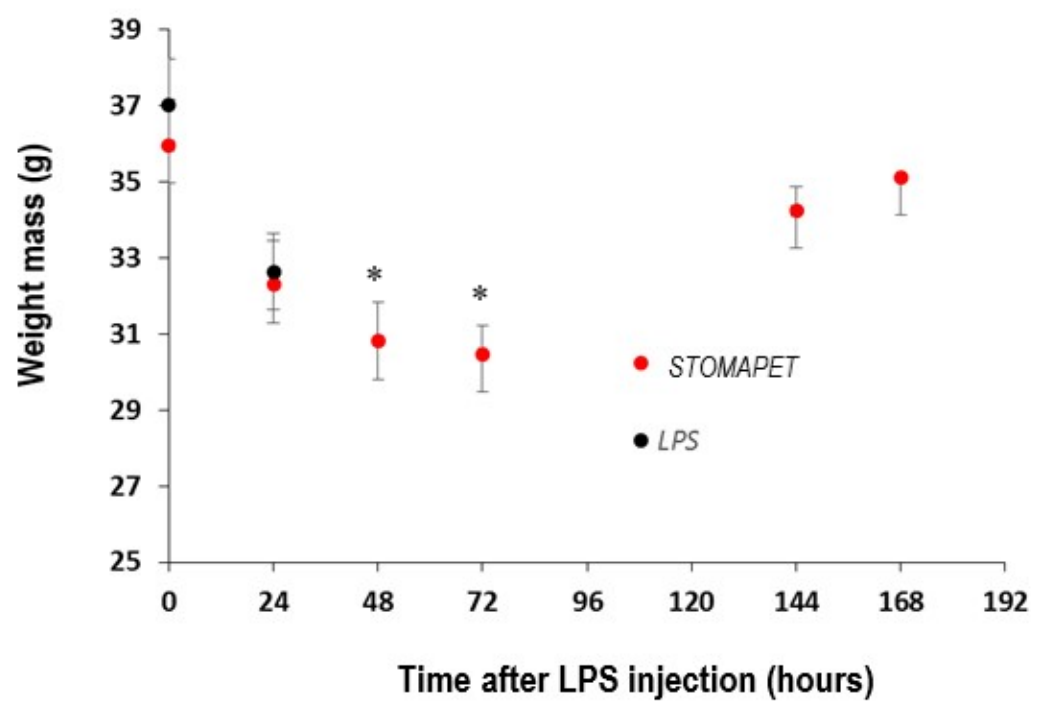

Figure 7. The decrease in body mass caused by LPS-induced endotoxemia is ameliorated following treatment with STOMAPET. Body mass (g) analyzed according to the time (hours) elapsed since the intraperitoneal injection with LPS (20 mg/kg mouse mass). Group 1 (black dot): $\mathrm{n}=5$ mice, Group 2 (red dot): $\mathrm{n}=5$ mice. Values are shown as mean \pm SEM. The significant decrease is considered at $\left.p<0.05{ }^{*}\right)$. 
Body temperature was measured in mice from the two groups at the time of LPS injection and once every $24 \mathrm{~h}$ after injection for $168 \mathrm{~h}$. The temperature was measured in the abdominal area. Prior to LPS injection, temperatures ranged from $34.2^{\circ} \mathrm{C}$ to $35.7^{\circ} \mathrm{C}$. After $24 \mathrm{~h}$ from the time of LPS injection, the temperature of Group 1 mice fell below the detection limit of the device and the method of measurement. However, the body temperature for Group 2 mice could be measured throughout the experiment $(0-168 \mathrm{~h})$ and was within normal limits.

\subsubsection{Veterinary Case-Reports}

Due to good results obtained in preclinical studies on mice, we decided to test if the product has the same beneficial impact in clinic. Periodontal disease has a high prevalence in companion animals, with eight out of ten dogs over the age of three suffering from dental problems according to the American Veterinary Medical Association [25].

Case 1

- Female half-breed dog, 14 years old

- Diagnosis: Hodgkin's lymphoma, from the age of 4; treated symptomatically and kept alive by the attending physician through the devotion of the owner.

- In this dog, a year ago, a stomatitis overlapped with an unbearable halena. The attending physician proposed euthanizing him, but the owner did not want to and isolated him in a room. After symptomatic treatments (antibiotics in general, after antibiogram and general supportive treatments), the treatment with STOMAPET was started, at $1 \mathrm{drop} / \mathrm{kg}$ of $2 \times /$ day for 3 months.

- After this period, the pain disappeared, the animal consuming the food well, the green-yellow secretions that were present 3 months ago also disappeared and no remnants of mucosa appeared. After the period of 3 months, the treatment was continued (application of drops in the oral cavity only once/day in a dose of 1 drop/kg/day). Currently, after 1 year, the dog is alive and stable.

\section{Case 2}

- 7-year-old male half-breed cat

- Diagnosis: Type 1 diabetes (insulin dependent)

- Treatment: insulin 3 IU/2 times/day and symptomatic treatment

- The cat underwent diabetes tests, but had a gingival infection and a devitalized canine broke. 3 days of treatment with antibiotic followed, descaling was used, but the canine root could not be extracted, the area remaining open and very painful. Then the oral treatment was applied with STOMAPET $1 \mathrm{drop} / \mathrm{kg} / \mathrm{day}$ for 30 days, without any other local treatment; after this period, the cat only had a gingival infection and the place where the canine root was observed was completely healed. Currently, the patient's evolution is good, following the treatment and monitoring for diabetes.

\section{Case 3}

- 12-year-old Yorkshire dog

- Diagnosis: Ascites, gingivitis, and dental tartar

- Treatment of hepatoprotective ascites and abdominal transudate evacuation puncture.

- Before descaling for 5 days, the dog was treated with an antibiotic. After anesthesia followed by descaling, STOMAPET was applied in the oral cavity, in a dose of $1 \mathrm{drop} / \mathrm{kg} /$ day for 30 days. Very strangely, after this 30-day treatment, the dog only had no ascites (no more fluid accumulated in the abdomen) and the oral infection disappeared completely, with no recurrences. 


\section{Discussions}

\subsection{HPLC Analysis}

As it was stated by Clifford et al., the occurrence of caffeoylquinic acids in E. cannabinum, mainly chlorogenic acids, within the Asteraceae family members is common and typical [26].

Phenolic compounds including flavonoids are considered as valuable chemotaxonomic markers in the Asteraceae family [27]. Previous studies showed that E. cannabinum contains mainly quercetin and kaempferol glycosides with rutin as a dominating compound [28]. Additionally, phenolic and organic acids are primary anti-inflammatory ingredients of TMX, a traditional Chinese Medicine based on dried roots of Inula helenium L. and Inula racemosa Hook [29].

\subsection{In Vitro Studies}

Cell viability after treatment with various concentrations of STOMAPET was determined using a culture and evaluated by MTS assay. STOMAPET has a high stimulatory effect on human monocytes proliferation. In LPS-stimulated macrophages, the protective effect was exerted at high doses after $24 \mathrm{~h}$ of exposure. Previous results showed that an ethanolic extract of I. helenium [30] and other specific compounds of Inula-isoalantolactones and seco-eudesmanolides significantly suppressed LPS-induced NF- $\mathrm{kB}$ activation, as well as phosphoinositide 3-kinases (PI3K) and protein kinase B (AKT) phosphorylation [19,31]. Moreover, several extracts of E. perfoliatum showed anti-inflammatory activity against LPS-stimulated macrophages by inhibition of NO release, downregulation of cytokines and chemokines with eupafolin and a dimeric guaianolide having prominent NO inhibiting activity [8].

\subsection{In Vivo Studies}

\subsubsection{Preclinical Studies}

STOMAPET prevents mortality and improves over time the decrease in body mass caused by LPS-induced endotoxemia.

The results are similar with previous studies showing that the ethanol extract of Inula helenium $\mathrm{L}$. activates p38 mitogen-activated protein kinase (MAPK)/nuclear factor erythroid 2-related factor 2 (Nrf2)/heme oxygenase (HO-1) pathways in RAW264.7 cells, reducing inflammation in cecum ligation and puncture-induced septic mice [32]. Moreover, in another murine model of peritonitis, eupatoriopicrin, a compound found in Eupatorium species, efficiently suppressed LPS-induced phosphorylation of p38 MAPK and ERK and attenuated neutrophil infiltration [33].

Furthermore, STOMAPET prevents the drop in temperature caused by LPS-induced endotoxemia.

Previously, in the same in vivo model, we showed that preventive administration of Eupatorium extracts improves mouse survival and inhibits proinflammatory cytokines expression. A correlation between chemical composition and pharmacological effect could not be found, coming to the conclusion that both polar and nonpolar compounds are involved in exerting preventive effects [34].

\subsubsection{Veterinary Case-Reports}

Periodontal disease is a widely found inflammatory state caused by bacterial plaque in the periodontium, and a suitable model to investigate STOMAPET. The clinical cases presented showed promising perspectives for application in the veterinary area. There are few natural therapeutic alternatives for periodontal disease management-Aesculus hippocastanum (horse chestnut) leaf extract that could be an effective agent for clinical prevention and treatment of periodontitis by inhibiting the gelatinase and collagenase activities, which can detach periodontal ligaments from alveolar bone [35], berberine demonstrated in vitro an inhibitory effect on Porphyromonas gingivalis lipopolysaccharide-enhanced metalloproteinases activities of macrophages [36], Lippia sidoides essential oil reduces the scores for plaque-bacteria, calculus, gingivitis, and the inflammatory infiltrate [37]. 


\section{Conclusions}

STOMAPET was designed as a product with immunomodulating and antiinflammatory properties based on well-known and proven actions of the two component plants-Eupatorium cannabinum and Inula helenium. Preclinical studies confirmed the product safety and its pharmacological potential. The results of the veterinary case reports are also encouraging. More studies are needed to find the precise mechanism of action in correlation to chemical composition.

\section{Patents}

STOMAPET is the subject of a patent application to the State Office for Inventions and Trademarks, Romania (A2016/00888/23.11.2016-“Process for preparing a phytotherapeutic product with immunomodulatory action meant to be used in periodontitits therapy in pets").

Author Contributions: Conceptualization, A.G. and L.I.; HPLC analysis, S.N.; in vitro studies, G.N.; preclinical in vivo studies, G.N. and V.D.; clinical in vivo studies, C.F. and A.-M.G.; writing-original draft preparation, A.G.; writing-review and editing, C.I.; supervision, R.A. All authors have read and agreed to the published version of the manuscript.

Funding: This research was supported by the Ministry of Research and Innovation in the frame of the project PN.19.41.01.01/2018, CORE Program.

Conflicts of Interest: The authors declare no conflict of interest.

\section{References}

1. Carrillo-Hormaza, L.; Mora, C.; Alvarez, R.; Alzate, F.; Osorio, E. Chemical composition and antibacterial activity against Enterobacter cloacae of essential oils from Asteraceae species growing in the Páramos of Colombia. Ind. Crops Prod. 2015, 77, 108-115. [CrossRef]

2. Wen, C.C.; Chen, H.M.; Yang, N.S. Developing Phytocompounds from Medicinal Plants as Immunomodulators. Adv. Botanic. Res. 2012, 62, 197-272.

3. Nogueira Sobrinho, A.C.; de Morais, S.M.; de Souza, E.B.; dos Santos Fontenelle, R.O. The genus Eupatorium, L. (Asteraceae): A review of their antimicrobial activity. J. Med. Plant Res. 2017, 11, 43-57.

4. Choi, J.G.; Lee, H.; Hwang, Y.H.; Lee, J.S.; Cho, W.K.; Ma, J.Y. Eupatorium fortunei and Its Components Increase Antiviral Immune Responses against RNAViruses. Front. Pharmacol. 2017, 8, 51. [CrossRef]

5. Shin, J.I.; Jeon, Y.J.; Lee, S.; Lee, Y.G.; Kim, J.B.; Kwon, H.C.; Kim, S.H.; Kim, I.; Lee, K.; Han, Y.S. Apoptotic and Anti-Inflammatory Effects of Eupatorium japonicum Thunb. in Rheumatoid Arthritis Fibroblast-Like Synoviocytes. Biomed. Res. Int. 2018, 9, 1383697. [CrossRef]

6. Chu, C.; Yao, S.; Chen, J.; Wei, X.; Xia, L.; Chen, D.; Zhang, J. Eupatorium lindleyanum DC. flavonoids fraction attenuates lipopolysaccharide-induced acute lung injury in mice. Int. Immunopharmacol. 2016, 39, 23-33. [CrossRef]

7. Chakravarty, A.; Mazumder, T.; Chatterjee, S. Anti-Inflammatory Potential of Ethanolic Leaf Extract of Eupatorium adenophorum Spreng. Through Alteration in Production of TNF- $\alpha$, ROS and Expression of Certain Genes. Evid Based Complement. Altern. Med. 2011, 2011, 471074. [CrossRef] [PubMed]

8. Maas, M.; Deters, A.M.; Hensel, A. Anti-inflammatory activity of Eupatorium perfoliatum L. extracts, eupafolin, and dimeric guaianolide via iNOS inhibitory activity and modulation of inflammation-related cytokines and chemokines. J. Ethnopharmacol. 2011, 137, 371-381. [CrossRef]

9. Liu, P.Y.; Liu, D.; Li, W.H.; Zhao, T.; Sauroil, A.; Gu, Y.C.; Shi, W.; Zhang, M.L. Chemical Constituents of Plants from the Genus Eupatorium (1904-2014). Chem. Biodiv. 2015, 12, 1481-1515. [CrossRef]

10. Wang, F.; Zhong, H.; Fang, S.; Zheng, Y.; Li, C.; Peng, G.; Shen, X. Potential Anti-inflammatory Sesquiterpene Lactones from Eupatorium lindleyanum. Planta Med. 2018, 84, 123-128. [CrossRef]

11. Kalola, J.; Shah, R.; Patel, A.; Lahiri, S.K.; Shah, M.B. Anti-inflammatory and immunomodulatory activities of Inula cappa roots (Compositae). J. Complement. Integr. Med. 2017, 14, 83. [CrossRef] [PubMed]

12. Gierlikowska, B.; Gierlikowski, W.; Bekier, K.; Skalicka-Wozniak, K.; Czerwinska, M.; Kiss, A. Inula helenium and Grindelia squarrosa as a source of compounds with anti-inflammatory activity in human neutrophils and cultured human respiratory epithelium. J. Ethnopharmacol. 2020, 249, 112311. [CrossRef] [PubMed] 
13. Park, Y.N.; Lee, Y.J.; Choi, J.H.; Jin, M.; Yang, J.H.; Li, Y.; Lee, J.; Li, X.; Kim, K.J.; Son, J.K.; et al. Alleviation of OVA-induced airway inflammation by flowers of Inula japonica in a murine model of asthma. Biosci. Biotechnol. Biochem. 2011, 75, 871-876. [CrossRef] [PubMed]

14. Gao, S.; Wang, O.; Tian, X.H.; Li, H.L.; Shen, Y.H.; Xu, X.F.; Wu, G.Z.; Hu, Z.L.; Zhang, W.D. Total sesquiterpene lactones prepared from Inula helenium L. has potentials in prevention and therapy of rheumatoid arthritis. J. Ethnopharmacol. 2017, 196, 39-46. [CrossRef] [PubMed]

15. Chun, J.; Choi, R.J.; Khan, S.; Lee, D.S.; Kim, Y.C.; Nam, Y.J.; Lee, D.U.; Kim, Y.S. Alantolactone suppresses inducible nitric oxide synthase and cyclooxygenase-2 expression by down-regulating NF- $\mathrm{KB}, \mathrm{MAPK}$ and AP-1 via the MyD88 signaling pathway in LPS-activated RAW 264.7 cells. Int. Immunopharmacol. 2012, 14, 375-383. [CrossRef]

16. Qin, J.J.; Zhu, J.X.; Zeng, Q.; Cheng, X.R.; Zhang, S.D.; Jin, H.Z.; Zhang, W.D. Sesquiterpene lactones from Inula hupehensis inhibit nitric oxide production in RAW264.7 macrophages. Planta Med. 2012, 78, 1002-1009. [CrossRef]

17. Cheng, X.; Zeng, Q.; Ren, J.; Qin, J.J.; Zhang, S.; Shen, Y.; Zhu, J.; Zhang, F.; Chang, R.J.; Zhu, Y.; et al. Sesquiterpene lactones from Inula falconeri, a plant endemic to the Himalayas, as potential anti-inflammatory agents. Eur. J. Med. Chem. 2003, 46, 5408-5415. [CrossRef]

18. Ding, Y.H.; Song, Y.D.; Wu, Y.X.; He, H.Q.; Yu, T.H.; Hu, Y.D.; Zhang, D.P.; Jiang, H.C.; Yu, K.K.; Li, X.Z.; et al. Isoalantolactone suppresses LPS-induced inflammation by inhibiting TRAF6 ubiquitination and alleviates acute lung injury. Acta Pharmacol. Sin. 2019, 40, 64-74. [CrossRef]

19. Chen, X.; Tang, S.A.; Lee, E.; Qiu, Y.; Wang, R.; Duan, H.Q.; Dan, S.; Jin, M.; Kong, D. IVSE, isolated from Inula japonica,suppresses LPS-induced NO production via NF- $\mathrm{B}$ and MAPK inactivation in RAW264.7 cells. Life Sci. 2015, 124, 8-15. [CrossRef]

20. Hernandez, V.; del Carmen Recio, M.; Manez, S.; Prieto, J.M.; Giner, R.M.; Rios, J.L. A mechanistic approach to the in vivo anti-inflammatory activity of sesquiterpenoid compounds isolated from Inula viscosa. Planta Med. 2001, 67, 726-731. [CrossRef]

21. Damre, A.A.; Damre, A.S.; Saraf, M.N. Evaluation of sesquiterpene lactone fraction of Saussurea lappa on transudative, exudative and proliferative phases of inflammation. Phytother. Res. 2003, 17, 722-725. [CrossRef] [PubMed]

22. Sarer, E.; Gokbulut, A. Isolation and quantification of alantolactone/isoalantolactone from the roots of Inula helenium subsp. Turcoracemosa. Turk. J. Pharm. Sci. 2013, 10, 447-452.

23. Fernandes, F.; de A Batista, S.; Medeiros, D.; Santos, F.; Medeiros, A. Development of a rapid and simple HPLC-UV method for determination of gallic acid in Schinopsis brasiliensis. Reb. Bras. Farmacogn. 2015, 25, 208-211. [CrossRef]

24. Soromou, L.W.; Jiang, L.; Wei1, M.; Chen, N.; Huo, M.; Chu, X.; Zhong, W.; Wu, Q.; Balde, A.; Deng, X.; et al. Protection of mice against lipopolysaccharide-induced endotoxic shock by pinocembrin is correlated with regulation of cytokine secretion. J. Immunotoxicol. 2014, 11, 56-61. [CrossRef]

25. Albuquerque, C.; Morinha, F.; Requicha, J.; Martins, T.; Dias, I.; Guedes-Pinto, H.; Bastos, E.; Viegas, C. Canine periodontitis: The dog as an important model for periodontal studies. Vet. J. 2012, 191, 299-305. [CrossRef]

26. Clifford, M.N.; Knight, S.; Kuhnert, N. Discriminating between the six isomers of dicaffeoylquinic acid by LC-MSn. J. Agric. Food Chem. 2005, 53, 3821. [CrossRef]

27. Emerenciano, V.P.; Militão, J.S.L.T.; Campos, C.C.; Romoff, P.; Kaplan, M.A.C.; Zambon, M.; Brant, A.J.C. Flavonoids as chemotaxonomic markers for Asteraceae. Biochem. Systemat. Ecol. 2001, 29, 947. [CrossRef]

28. Piwowarski, J.; Waltenberger, B.; Stuppner, H.; Kiss, A.; Granic, S. The analysis of phenolic compounds from the aerial parts of Eupatorium cannabinum L. subsp. Cannabinum. Biochem. Systemat. Ecol. 2018, 79, 37-43. [CrossRef]

29. Gao, X.; Ma, Y.L.; Wang, Z.W.; Bia, R.B.; Zhang, P.; Hu, F.D. Identification of anti-inflammatory active ingredients from Tumuxiang by ultra-performance liquid chromatography/quadrupole time-of-flight-MSE. Biomed. Chromatogr. 2018, 32, e4179. [CrossRef]

30. Lee, S.G.; Kang, H. Anti-neuroinflammatory Effects of Ethanol Extract of Inula helenium L (Compositae). Trop. J. Pharm. Res. 2018, 15, 521-526. [CrossRef]

31. Yuan, C.B.; Tian, L.; Yang, B.; Zhou, H.Y. Isoalantolactone protects LPS-induced acute lung injury through Nrf2 activation. Microb. Pathog. 2018, 123, 213-218. [CrossRef] 
32. Park, E.J.; Kim, Y.M.; Park, S.W.; Kim, H.J.; Lee, J.H.; Lee, D.U.; Chang, K.C. Induction of HO-1 through p38 MAPK/Nrf2 signaling pathway by ethanol extract of Inula helenium L. reduces inflammation in LPS-activated RAW 264.7 cells and CLP-induced septic mice. Food Chem. Toxicol. 2013, 55, 386-395. [CrossRef]

33. Michalak, B.; Piwowarski, J.; Granica, S.; Waltenberger, B.; Atanasov, A.; Khan, S.; Breuss, J.; Uhrin, P.; Zyzynska-Granica, B.; Stojakowska, A.; et al. Eupatoriopicrin Inhibits Pro-inflammatory Functions of Neutrophils via Suppression of IL-8 and TNF-alpha Production and p38 and ERK 1/2 MAP Kinases. J. Nat. Prod. 2019, 82, 375-385. [CrossRef]

34. Grigore, A.; Neagu, G.; Dobre, N.; Albulescu, A.; Ionita, L.; Ionita, C.; Albulescu, R. Evaluation of antiproliferative and protective effects of Eupatorium cannabinum L. Extracts. Turk. J. Biol. 2018, 42, 334-344. [CrossRef]

35. Kim, S.E.; Kim, T.H.; Park, S.A.; Kim, W.T.; Park, Y.W.; Ahn, J.S.; Jeong, M.; Kim, M.Y.; Seo, K. Efficacy of horse chestnut leaf extract ALH-L1005 as a matrix metalloproteinase inhibitor in ligature-induced periodontitis in canine model. J. Vet. Sci. 2017, 18, 245-251. [CrossRef]

36. Tu, H.P.; Fu, M.M.; Kuo, P.J.; Chin, Y.T.; Chiang, C.Y.; Chung, C.L.; Fu, E. Berberine's effect on periodontal tissue degradation by matrix metalloproteinases: An in vitro and in vivo experiment. Phytomedicine 2013, 20, 1203-1210. [CrossRef]

37. Girao, V.; Nunes-Pinheiro, D.; Morais, S.; Sequeira, J.; Gioso, M. A clinical trial of the effect of a mouth-rinse prepared with Lippia sidoides Cham essential oil in dogs with mild gingival disease. Prev. Vet. Med. 2003, 59, 95-102. [CrossRef]

(C) 2020 by the authors. Licensee MDPI, Basel, Switzerland. This article is an open access article distributed under the terms and conditions of the Creative Commons Attribution (CC BY) license (http://creativecommons.org/licenses/by/4.0/). 